\title{
AEROMAGNETIC MAP OF THE PLYMOUTH-LACONIA AREA, NEW HAMPSHIRE
}

\author{
GEOPHYSICAL INVESTIGATIONS \\ MAP GP-892
}

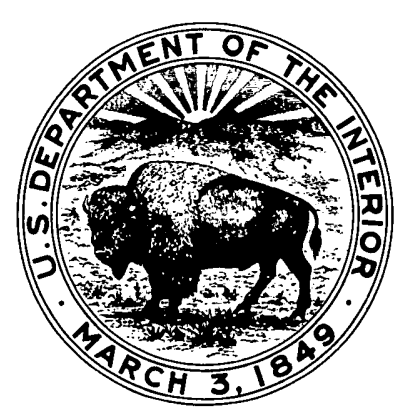

PUBLISHED BY THE U.S. GEOLOGICAL SURVEY 